\title{
The Historical Influence of Christianity in Cultural Communication between China and the West
}

\author{
Yongxia Bai \\ School of Hu man ities \\ Xi'an Shiyou University \\ Xi'an, China
}

\begin{abstract}
Christianity plays a significant role in cultural communication between China and the west in modern and contemporary Chinese history. With powerful and aggressive color, in the long history, Christianity was taking positive effects on Chinese science and technology development, and was imposing negative influence on politics in China as well; but Christianity, which is more amicable in the contemporary world, takes an active part in cultural exchange between China and the Western. The diversity between the two situations is resulted from the fact that religious doctrine of Christianity, and determined by Christianity characteristics; it develops with history. In the present cultural communication, it is supposed to view and comprehend Christianity from a de veloping perspective.
\end{abstract}

Keywords-Christianity; cultural communication between China and the west; characteristics

\section{INTRODUCTION}

Cultural exchange is an important factor for the cultural progress and development in all countries and also a power to promote the understanding of the whole human society so as to eliminate differences. During the five- thousand years of development of China, with the continuous development of social, political and economy, it has gradually established relations with countries in the world from near to far, where the medium that works well is cultural exchange. The forms of cultural exchange are diverse including materials such as silk, porcelain, tea, grain and spirit such as philosophy, religion, literature, art and so on. In different periods in the history, main media for cultural exchanges among countries are diverse.

During Han Dynasty, the cultural exchanges between China and the West Asian countries were conducted mainly through trade caravans on the Silk Road, as important media for communication, Chinese silk and plants from the Western Regions were outshining in the period, which laid a sold foundation for the communication between China and western countries in the future. In the dynasties of Wei, J in and North and South, Buddhism became a link for cultural exchanges between China and many foreign countries, during that period, a great number of Buddhist treasures were produced, and China attracted a great number of many famous monks came to China, who translated a lot of important classics. During Sui and Tang dynasties, all kinds of media were active, and China' s cultures, technologies and goods brought great influence to the countries surrounding, greatly promoting the cultural development around the world. In North Song Dynasty, the cultural exchange channels were changed to sea through which, China technologies, ceramics and silk were transported every corner around the world, in the meantime, foreign perfume, treasure and ivories reached China well. During the period, Buddhism was still active, influencing the countries around. In Ming Dynasty, Zheng He' s Travel to the West tremendously promoted the transmission of Chinese culture and brought back the western scientific knowledge and mechanical mapping and so on.

During the development of Chinese history, the role of Chris tianity was not obvious for the cultural exchange between China and the West. However, starting from Qing Dynasty up to the modern times, the historic role of Christianity became stronger and stronger, from Qing Dynasty when Emperor Kangxi kept close relations with churchmen fro $m$ the West, to Taiping Rebellion at the end of Qing Dynasty up to the Republic of China when Chiang Kai-shek and his wife became believers, Christianity could be found in the cultural exchange between China and the West. In the modern history, the role of Christianity in the cultural exchange between China and the West was argued for about one hundred years, and diverse discussions were often conducted upon the Christianity and the cultural exchange, of which, some showed or stated the development history of Christianity in the modern history in China[1-3] or critically analy zed the background of history and politics of Christianity[1,4,5], or compared the active and passive roles of Christianity in the China' s development $[3,6]$ and so on. This article aims to analyze the roles of Christianity in Chinese history and the cultural exchange between the East and the West in Contemporary China, explaining the two different perspectives through deeply analyzing the features of Christianity.

\section{INVASI VE CHRISTIANITY AND IT S TWO-SIDE INFLUENCES IN HISTORY}

In fact, the large-scale introduction of Christianity to China took place four times: In Zhenguan Years of Tang Dynasty, Olopen, Nestoriaans of Christianity, created Jingjiao, the diplomatic corps in Yuan Dynasty ever submitted a written statement to Pope for missionizing in China (namely Erkeun), Michele Ruggieri and Ricci who missionized in China at the end of Ming Dynasy as well as Protestantism developing in the later Qing Dynasty. As for the four missionizing of Christianity 
in China, the first three disappeared in traditional Chinese culture, bringing no shock to traditional Chinese culture and political system, yet the last missionizing was accompanied with the rising of capitalism around the world and the collapse of feudalism in China, which shocked China, so the discussion on Christianity is mainly focused on the history after Qing Dynasty.

\section{A. Missionization in Modern Times}

In modern times, famous missionaries in China mainly include: Rutherford Alcock, a British diplomat during the period of Opium War, Aldersey, a woman missionary who created the first Western-style women's school in China, Sherwood Eddy, an evangelist from the USA, who promoted the "class reconciliation" and Julio Aleni who wrote books such as Sanshan Lun xue Ji, Tian zhu Jiangsheng Yan xing Jilue, Huizui Yaozhi, Wanyou Zhenyuan, Dizui Zhenggui, where a lot of refe rences to Confucianism were cited. During the period, Christianity played a variety of roles in Chinese and Western cultural exchanges, so the evaluations on the missionary activities in China were complicated.

\section{B. Positive Influences}

Positive role: technical transmission in cultural exchanges: During the period, Christianity promoted the science transmission in China, most of current famous universities were established by missionaries from the west such as Fudan University, Fu Jen Catholic University, Yanjing University, Qilu University and so on, which not only promoted the rapid development of modern sciences but also adopted many homeless children. In the meantime, due to the domestic strife and foreign aggression in China, the people were pool and the government was difficult to deal with it. And the western missionaries offered positive aid in fundraising, rescuing victims, repairing embankments and flood control in China, besides, the activities promoted the trans mission of Christianity in China.

\section{Negative Influences}

Negative role: political oppression in cultural exchanges. The political background for missionary to preach in this period caused a great controversy, which is still in discussion. In order to stay in China, the missionaries were forced to jo in some commercial companies with political intentions for some translation work, and when the war occurred, some missionaries would serve as envoys, consuls, translators or negotiators to participate in the war, and as civil officials after the war ended. Seen the nomination, though the missionaries have get rid of identities of missionaries after playing as politicians but just act as governmental officials. However, seen from the whole history, the missionaries played some roles in replacing outdated political systems with new ones. In addition, after the missionaries become governmental officials, their claims and behaviors have conflicts with their theories, which can often seen in history, for example Karl Friedlich Gutzlaff, a British intelligence official in the stage of Opium War, Peter Parker who claimed the USA government should speed up its invasion to China. Such conditions had lasted up to the 1950s, the commissary named John Leighton Stuart, the former president of Yanjing University, served as American ambassador in China.

\section{Analysis of Contradictory Phenomena}

The contradictory phenomenon also became the root causes for different evaluation on Christianity in China and all kinds of anti- Christianity activities. Zhuo Xinping[7], researcher of Chinese Academy of Social Sciences, showed his analysis, he thought that a belief system should contain spiritual pursuit and social participation. The former is an ultimate care of the believers yet the latter gets involved in the society, for the latter is influenced by the society in all aspects, which inevitably brings a complicated result.

\section{CURRENT KIND CHRISTIANITY AND IT S ROLE INTHE \\ CULTURAL EXCHANGES BETWEEN CHINA AND THE WEST}

Currently, Christianity is the world's largest religion, which plays an important role in major economic and political giants, by the end of 2014, there were 2.4 billion believers, occupying about $1 / 3$ of the world's population. In China, Christianity is the third largest religion, with the continuous development of the society, the number of believers grow rapidly. During the cultural exchanges with the West, the meaning of Christian culture for the western countries is the same as that for the traditional culture in China. Therefore, in order to keep close cooperation and communication with all countries around the world, first, it is necessary to understand the cultural development course of the countries, besides the western civilizations such as politics, philosophy, literature, music and so on all are filled with Christianity.

With the development of society, compared to those in history, the Western missionaries in China have more pure identities and background, and the political factors of participation have been greatly weakened. The Chinese who enter the Western countries, while bringing the traditional Chinese culture, are also constantly integrated to the Christian culture. The coexistence of the two cultures has promoted the interrelationship and mutual understanding between China and the Western countries. For China, it shall not exclude the Western culture, instead, it shall keep the characteristics of all cultures, and make Chinese civilization and ideas serve the people around the world on the principle "Coexist though different".

\section{ANALYSIS OF DIFFERENT PREACHING- CHARACTERISTICS OF CHRISTIANITY}

After comparing the roles of Christianity in the Chinese and Western cultural exchanges in history and the Chinese and Western cultural exchanges in modern times, we find an interest phenomenon, that is, Christianity is of constantly selfrenewal and improvement. In fact, not only the role of Christianity in Chinese and Western cultural exchanges will change with the history, but also its role in the Western culture is constantly will be advancing with the times. In other words, the reason why the Western culture has developed so rapidly and why modern science originated in the West are all related to the continuous improvement of Christianity. From its birth up to now, the Christian culture has not disappeared instead, it 
has been in a trend of renais sance in today's Western society, because Christianity has been adjusted constantly through the continuous reinterpretation of the Bible according to the development of the times and changes of psychological needs of the people. When evaluating the Christian Culture and Western Literary Tradition written by Liu Jianjun, Yang Lijuan [8] gave an example: God was initially a symbol of salvation power; and a strength of order at the Middle Ages; and a power of love at the peak time of the Middle Ages; This understanding had continued up to the late nineteenth century and developed into an embodiment of "eternal love" and "eternal justice"; in the mid-20th century, with the rising of modern and post modern theories, God as a "noble spirit of the relationship structure" began to become a trend for new interpretation. Adapted to the connotation of God, the God in the Christian culture also changes from initial external "logos" gradually to God at heart and God with internal and external combination.

Christianity can not only adapt to social changes through changes of its own but also keep being renovated through a traditional mode which is accepted by the people and used by the people[9], the characteristics which make it different from others also influence its nature, contents and significance for dissemination across the country.

\section{CONCLUSION}

Christianity plays am important role in the modern history and China and the up-to-date Chinese and Western cultural exchanges, in the future, the development of Chinese and Western cultures cannot be separated from the Christianity. In history, Christianity brought modern science to China and negative influence to the politics. After entering the modern society, Due to the self improvement, the missionary activities of Christianity are improving as well, for China, it needs to adopt policies more inclusive to meet the foreign culture and drive the world through the thought "Coexist but different".

\section{REFERENCES}

[1] Zhang Kaiyuan, Transmission and Rooting - Collection of Dissucion on Christianity and Chinese and Western Culture Exchanges [M]. Guangdong People's Publishing House, 2005.

[2] Liang Biying, Americian Missionaries and Chinese and Western Cultural Exchanges in Modern History [J]. Journal of Sun Yatsen University, Philosophy and Social Science Edition, , 1989, (3): 61-69

[3] Zhang Bo, Simple Discussion on Transmssion Mode of Christianity in Late Ming Dynasty and Early Qing Dynasty-Thought Based on Missionaries and Chinese and Western Cultural Exchanges[J]. Reading Essence, 2014, (18).

[4] Cao Sai, Christianity in Beijing in Ming and Qing Dynasties and Chinese and Western Cultural Exchanges [C], 2009

[5] History of Foreign Relaitons, Taiping Tianguo Rebilletion and Early Chinese and Western Exchanges in Modern Times [J]. Institutional Setup, 2015.

[6] Zhang Xinping, Discussion on Oringinal Sin of Christianity in Chinese and Western Cultural Exchanges [J]. Studies in World Religions, 1995, (2): 74-78.

[7] Zhang Xinping, Christianity Belief and Chinese and Western Culture [J].Tianfeng: Christianity in China, 2007, (2S): 34-37.

[8] Yang Lijuan, Discussion on Christianity and Traditional Western Literature-Evaluating Christianity Culture and Traditioanl Western
Literat ure writtend by Liu Jianjun [J]. Foreign Literature Studies, 2006, 28 (2): $170-172$.

[9] Cheng Weili, Christianity and Chinese and Wester Cultural Exchanges [J] Fudan Journal(Social Sciences Edition), 1987, (1): 55-60. 